\title{
Application of channel-belt scaling relationship to Middle Jurassic source- to-sink system in the Saishiteng area of the northern Qaidam Basin, NW China
}

\author{
Bing-Qiang Liu', Long-Yi Shao ${ }^{1 *}$, Xue-Tian Wang ${ }^{1}$, Ya-Nan Li ${ }^{1}$ and Jie Xu
}

\begin{abstract}
Palaeodrainage basin, as an important component of the source-to-sink system, contains critical information on provenance and palaeoenvironment. Previous studies indicate that the scaling relationships of source-to-sink system components generally follow power laws, and channel-belt thickness represents a reliable first-order proxy for the drainage area. In this study, a database of borehole cores and geophysical well logs of the Jurassic coal measures from Saishiteng area in the northern Qaidam Basin was used to reconstruct the palaeogeography, and to identify single-story channel-belts. Three palaeochannels, namely, River A, River B and River C, were identified which were persistent throughout the Dameigou and Shimengou Formations during the Middle Jurassic. The mean channel-belt thicknesses of River A, River B and River C in the Dameigou Formation were $9.8 \mathrm{~m}, 8.9 \mathrm{~m}$ and $7.9 \mathrm{~m}$, respectively, and those in the Shimengou Formation were $7.4 \mathrm{~m}, 6.2 \mathrm{~m}$ and $5.4 \mathrm{~m}$, respectively. We estimate the drainage area of three major rivers by using scaling relationships between drainage area and channel-belt thickness. The drainage areas of River A, River $B$ and River $C$ in the Dameigou Formation were $63.0 \times 10^{3} \mathrm{~km}^{2}, 50.1 \times 10^{3} \mathrm{~km}^{2}$ and $37.7 \times 10^{3} \mathrm{~km}^{2}$, respectively, and those in the Shimengou Formation were $32.3 \times 10^{3} \mathrm{~km}^{2}, 21.2 \times 10^{3} \mathrm{~km}^{2}$ and $15.3 \times 10^{3} \mathrm{~km}^{2}$, respectively. The drainage basin lengths of River A, River B and River $C$ in the Dameigou Formation were $300.4 \mathrm{~km}, 239 \mathrm{~km}$ and $180.2 \mathrm{~km}$, respectively, and those in the Shimengou Formation were $154.3 \mathrm{~km}$, $101.3 \mathrm{~km}$ and $73.1 \mathrm{~km}$, respectively. For both the Dameigou and Shimengou Formations, River A showed the largest scale, followed by River B and River C succeedingly, which was mainly determined by the stretch direction of provenance in the southern Qilian Mountains. The variations of channel-belt thickness, drainage area and drainage basin length between Dameigou and Shimengou Formations are the response of source-to-sink system to the transformation from extension to compression depression during the Middle Jurassic in the northern Qaidam Basin.
\end{abstract}

Keywords: Northern Qaidam Basin, Middle Jurassic, Source-to-sink system, Drainage basin, Channel-belt scaling relationship

\section{Introduction}

The comprehensive study on source-to-sink systems was originally proposed in the sub-project of Margins Program Science Plans 2004, which took the tectonic setting and denudation of source area, the transport process of sediments, and the final depositional pattern as a complete system (Allen 2008; Fuller and Marden 2010). This study comprehensively analyzes the interaction

\footnotetext{
* Correspondence: shaol@cumtb.edu.cn

${ }^{1}$ College of Geoscience and Surveying Engineering, China University of Mining and Technology (Beijing), Beijing 100083, China

Full list of author information is available at the end of the article
}

between internal and external factors that control the system, including the driving mechanism of sediments from source to sink, the evolution of palaeoprovenance, and the reconstruction of palaeodrainage systems (Allen 2005; Sømme et al. 2009; Romans and Graham 2013; Amorosi et al. 2016), so as to guide the prediction of corresponding geological events (Alexander et al. 2010; Berryman et al. 2010; Liu et al. 2017a). When source information is not preserved due to erosion, the source-to-sink system analysis can independently obtain information of the provenance and sediment supply through multiple methods (Helland-Hansen et al. 2016; Carter et al. 
2010). Therefore, the source-to-sink system theory has developed rapidly in energy exploration in recent years and will be widely applied in the research on deep-time palaeoenvironments (Sømme et al. 2013; Bhattacharya et al. 2016; Walsh et al. 2016).

Drainage basin, as an important component of sourceto-sink system (Fig. 1a), controls sediment supply from provenance to sedimentary basin, and then affects distribution characteristics and accumulation patterns of the strata in the sink (Davidson and Hartley 2014). It contains critical information of provenance and palaeoenvironment, however, due to late erosion, reconstruction of the source is difficult. Key information of drainage can be obtained from fluvial deposits, as which are mainly transported from the provenance by fluvial channels (Fig. 1b; Hovius 1998; Blum and Womack 2009). In recent years, a number of studies have investigated river data such as river channel dimensions, drainage area, and bankfull discharges, demonstrating that the scaling relationships of source-to-sink system components generally follow power laws, in which the channel-belt thickness (bankfull thickness) is positively correlated with the drainage area (Fig. 2; Syvitski and Milliman 2007; Blum et al. 2013; Anderson et al. 2016).
As a reliable first-order proxy for drainage area, channelbelt scaling relationship becomes an effective method for reconstructing the drainage area in source-to-sink system analysis (Davidson and Hartley 2014). Davidson and North (2009) predicted drainage area of the Middle Triassic of the Sydney Basin and the Upper Cretaceous of southwest Utah through the scaling relationship obtained from regional geomorphic curve. Xu et al. (2017) measured the lower channel-belt thickness and bankfull thickness of the Early Miocene in the Gulf of Mexico Basin and estimated the drainage areas corresponding to several different rivers by channel-belt scaling relationship. Milliken et al. (2018) reconstructed drainage basin evolution and sediment routing for the Cretaceous and Paleocene of the Gulf of Mexico by using fluvial scaling relationships.

The measurement of river channel dimensions is a prerequisite for applying channel-belt scaling relationship in drainage basin reconstruction. Compared to channel-belt width, channel-belt thickness (bankfull thickness) is more easily measured from well log, borehole and outcrop; also the river characteristics reflected by channel-belt thickness are more reliable (Miall 2006).

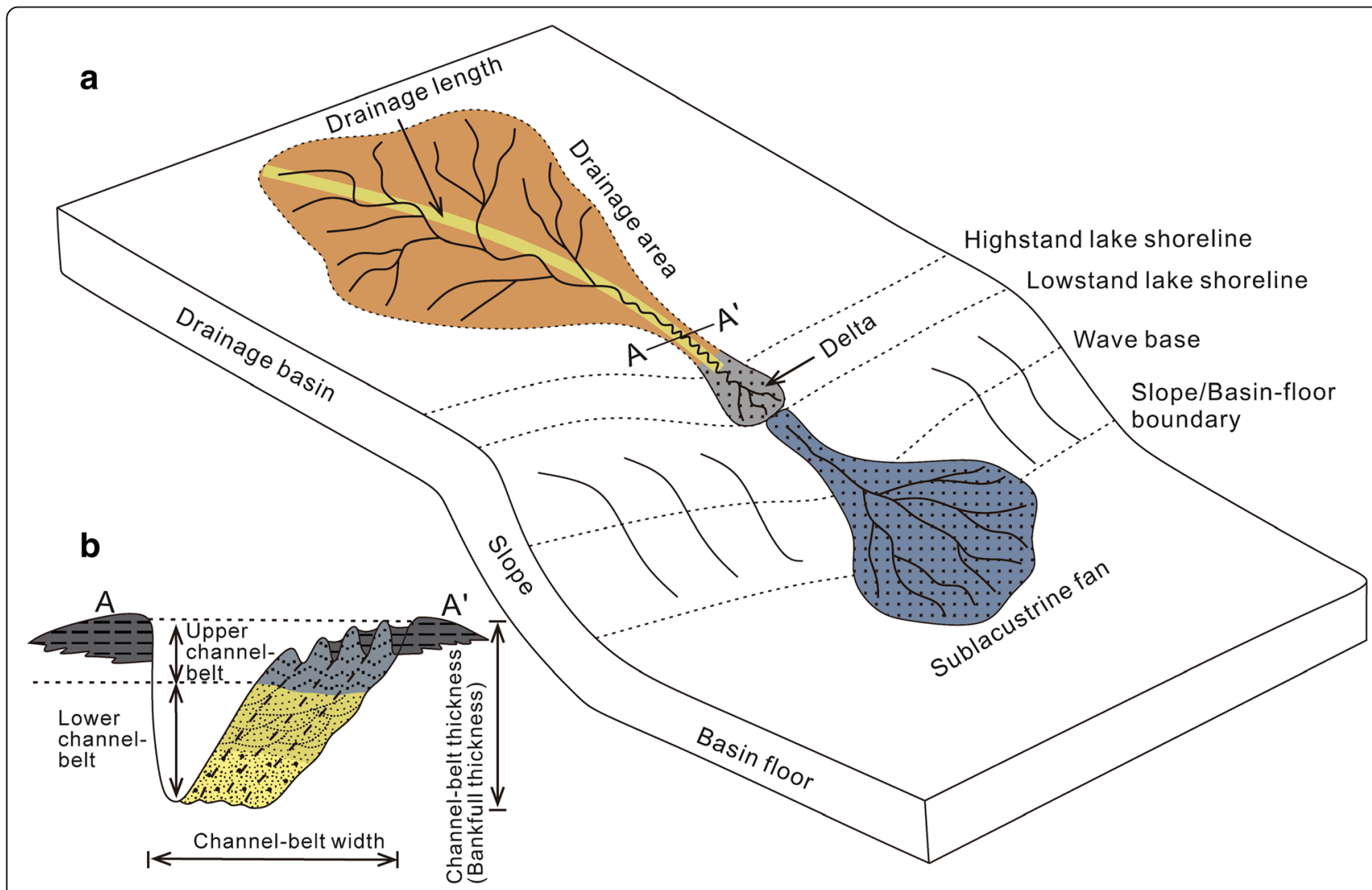

Fig. 1 Schematic diagram of a continental basin source-to-sink system. a Source-to-sink system components (modified from Blum et al. 2013); b Channel-belt deposits profile (modified from Saucier 1994) 


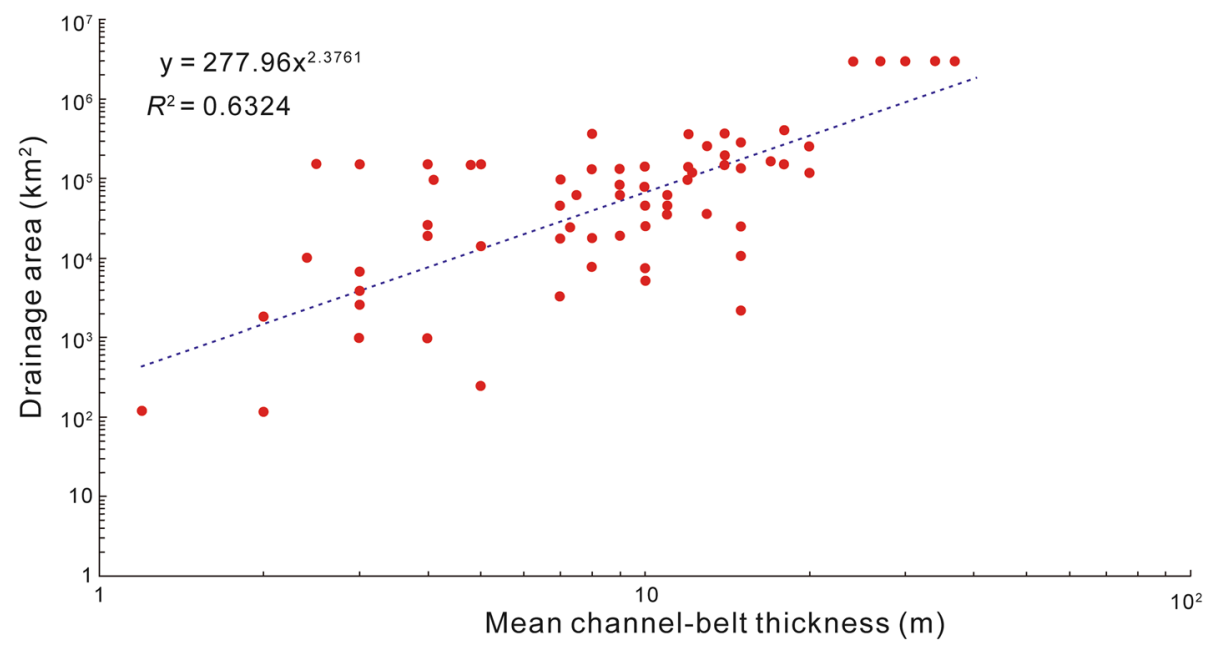

Fig. 2 Global scaling relationship between mean channel-belt thickness and drainage area (modified from Blum et al. 2013). $R^{2}$ : Coefficient of determination

As an important basin in northwestern China, the Qaidam Basin is rich in oil, coal and gas resources (Shao et al. 2014; Li et al. 2017). The Saishiteng area is a potential exploration area for coal resources of the Middle Jurassic in the northern Qaidam Basin (Zhao et al.2000; Li et al. 2014). The database of coal and oil boreholes in the Saishiteng area provides convenience for analysis of depositional environment and palaeogeography. The analysis showed that the depositional units developed during the Middle Jurassic included meandering river, delta and lacustrine facies. During the Middle Jurassic, sufficient siliciclastic materials were transported into the northern Qaidam Basin by rivers, and fluvial deposits occupied most of the Saishiteng area (Li et al. 2016). These fluvial deposits allow us to build the drainage areas for the Jurassic continental basin based on channel-belt scaling relationships.

In this study, borehole cores and geophysical well logs in the Saishiteng area were used to identify and measure river channel dimensions. The Middle Jurassic drainage areas of different rivers were estimated by channel-belt scaling relationships combined with analysis of basin sedimentary-tectonic evolution. We focus on the variation of channel-belt thickness from the Dameigou Formation to the Shimengou Formation of the Middle Jurassic, and try to reveal the relationship between river dimensions and tectonic evolution, and to improve the comprehension of the Jurassic source-to-sink system in the northern Qaidam Basin.

\section{Geological setting}

Formation and evolution of the Qaidam Basin is closely related to the intense activities of Tethys Himalaya tectonic domain. During Jurassic, Qaidam Basin was located in the area surrounded by Qiangtang Block, North
China Plate and Yangtze Plate, where early stress relaxation, post-orogenic extension, and late stress extrusion formed the fault-depression basin (Zhao et al.2000; Dai et al. 2003; Wu et al. 2005). The Saishiteng area is located in the northern part of Saishiteng depression which is a second-order tectonic unit in the northern Qaidam Basin (Fig. 3). The basement of Saishiteng depression predominantly consists of Upper Ordovician gneiss, phyllite, slates, tuff and quartzose sandstone in the northwestern and eastern parts, and Upper Ordovician granite and gabbro in the central part (Wang et al. 2006; Liu et al. 2013; Li et al. 2016). Dameigou and Shimengou Formations were deposited during the Middle Jurassic (Zhang 1998; Qian et al. 2018). The Dameigou Formation is equivalent to Middle Jurassic Aalenian and Bajocian Stages (Lu et al. 2009; Deng et al. 2017), which mainly consists of coarse- to fine-grained sandstones, siltstones, mudstones and coal seams. The Shimengou Formation is characterized by pebbly sandstones, coarse sandstones, siltstones with interbeds of coal seams, thick mudstones and shales (Fig. 4), corresponding to Middle Jurassic Bathonian and Callovian Stages (Lu et al. 2009; Deng et al. 2017). The sporo-pollen assemblages of Marattisporites, Cycadopites, and Cyathidites indicate a warm and humid palaeoclimate during Middle Jurassic in the northern Qaidam Basin (Yang et al. 2000; Dang et al. 2003).

Based on previous research of the northern Qaidam Basin and a large number of borehole analyses, $\mathrm{Li}$ et al. (2016) reconstructed palaeogeography of the Middle Jurassic in the study area by "single-factor analysis and multi-factor comprehensive mapping method" (Feng 2004) (Fig. 5). Saishiteng area shows the palaeogeographic pattern that meandering river and delta developed in the north, while lacustrine facies were mainly distributed in the south. Compared with the Dameigou 


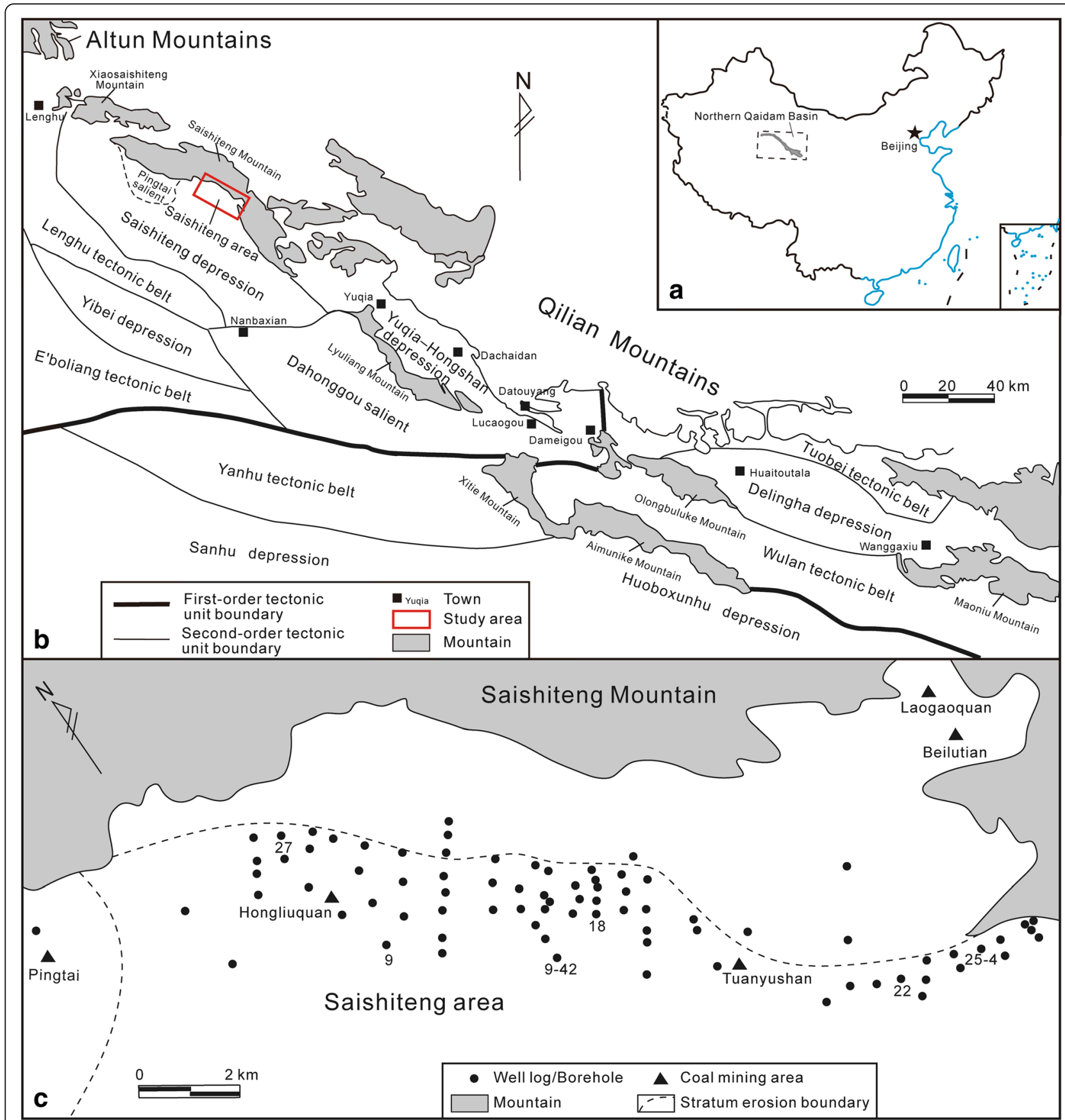

Fig. 3 Tectonic divisions of the northern Qaidam Basin and location of the study area. a Location of the northern Qaidam Basin, NW China; b Tectonic divisions of the northern Qaidam Basin (modified from Dai et al. 2003); Saishiteng area is located to the north of Saishiteng depression; c Position of well logs and boreholes in Saishiteng area (boreholes discussed in the following text are numbered)

Formation, more extensive lacustrine deposits developed during the depositional period of the overlying Shimengou Formation while meandering fluvial and delta deposits obviously decreased. Detrital zircon analysis indicates that Qilian Mountains continued to provide siliciclastic material to Saishiteng depression during Middle Jurassic through three major rivers ( $\mathrm{Li}$ et al. 2016; Yan 2017; Qian et al. 2018).

\section{Database and methodology}

\subsection{Database}

Due to limited Jurassic outcrops in the study area, it is difficult to observe the complete channel-belt successions in the field. In recent years, a large number of coal and oil boreholes have been drilled in the Saishiteng area (Fig. 3c), which enriched the database of well logs and facilitated the measurement of channel-belt thickness. 




Fig. 4 Comprehensive stratigraphic column of the Middle Jurassic of the borehole 18 (location shown in Fig. 3c) in Saishiteng area 




Based on the analysis of 81 well logs, the channel-belt thicknesses of three major rivers developed in the Dameigou and Shimengou Formations in Saishiteng area were measured. The three major rivers were named River A, River B and River C, respectively (Fig. 5).

\subsection{Single-story channel-belt recognition}

Major fluvial facies in littoral plains include channel belt, levee, crevasse splay and floodplain deposits (Fig. 6; Galloway 1981). Each depositional facies has special lithological assemblages, sedimentary structures and grain-size trends which correspond to specific geophysical well logs
(Fig. 6; Galloway 1981; Bridge and Tye 2000; Zhang et al. 2017). Therefore, these depositional facies can be identified by the well log patterns (e.g., gamma ray (GR), spontaneous potential (SP)).

Channel-belt deposits usually present an upward-fining succession, in which the lower channel belt mainly contains medium- to coarse-grained sandstone, and large trough crossbedding and planar crossbedding, while the upper channel belt is mainly composed of fine-grained sandstone, siltstone, and mudstone, with horizontal bedding at the top (Fig. 7; Saucier 1994; Hubbard et al. 2011; Bridge and Tye 2000). The deposits of floodplain, levee, 




Fig. 6 Gamma ray well log patterns of different depositional facies in fluvial depositional systems (modified from Galloway 1981)

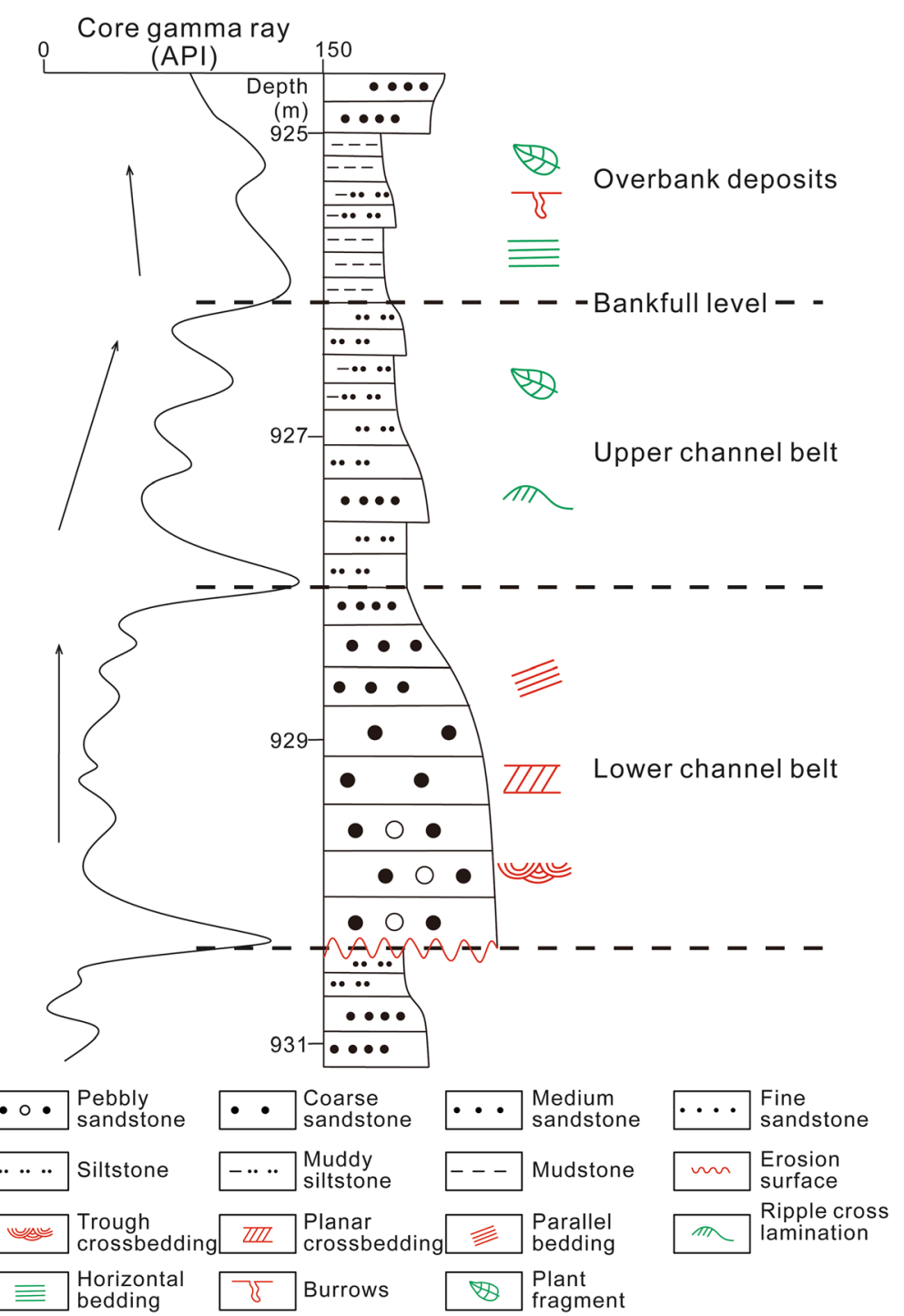

Fig. 7 Sedimentological and gamma ray well log characteristics of the Middle Jurassic channel-belt deposits of borehole 27 (location shown in Fig. 3c) in Saishiteng area 
and crevasse splay are finer, mainly siltstone and mudstone, which usually display an upward-coarsening succession (Fig. 6; Zhang 1990).

Channel belt generally shows different sedimentary characteristics in upstream and downstream. The upstream channel belt is mainly formed by lateral accretion while the downstream channel belt is prevailingly deposited by downstream translation. The former is characterized by a high sandstone content, while the latter has a heterogeneous package of sands and muds, showing a serrate, upward-fining pattern on well logging curve (Fig. 8b; Willis 1989; Durkin et al. 2015). The reconstructed palaeogeography showed that the fluvial types in the Saishiteng area were mainly meandering rivers, the majority of which belonged to downstream reaches with relatively stable channel, and displayed a certain degree of lithological heterogeneity (Figs. 5 and 7).

Abandoned channels are usually formed by river diversion or cut-off and dominated by fine-grained sediments (Galloway 1981). Sand fill occurs in upstream regions where the abandoned channel remains connected to the new active channel, while mud fill formed in downstream areas is located away from the active channel. In general, the gamma ray well log patterns of abandoned channels are characterized by a relatively thin, blocky or bell-shaped sandstone at the base and a thick, flat shale baseline on the top of the Jurassic coal measures in Saishiteng area (Fig. 8; Xu et al. 2017).

\subsection{Multi-story channel-belt deposits}

A complete channel deposits succession is the prerequisite for the measurement of channel dimensions (Lorenz et al. 1985; Blum et al. 2013; Holbrook and Wanas 2014), and the equilibrium relationship between sediment supply and accommodation space controls the preservation of channel deposits succession (Gibling 2006). The low-accommodation space with sufficient sediment supply tends to form multi-story channel-belt deposits, and the overlying channel often causes erosion on the underlying channel deposits. Multi-story channel-belt deposits cannot be used to measure the true thickness of single-story channel-belts, and should be identified and excluded in practice.

Multi-story channel-belt deposits mainly consist of massive blocky sandstone with interbeds of thin mudstone, which are often developed with erosional surfaces and display blocky interbeds of serrate GR well log curves (Fig. 8d; Xu et al. 2017). The rapid tectonic subsidence of the Middle Jurassic in Saishiteng area forms sufficient accommodation space, which favors the preservation of single-story channel deposits. Multi-story channel-belt deposits rarely provide a good opportunity

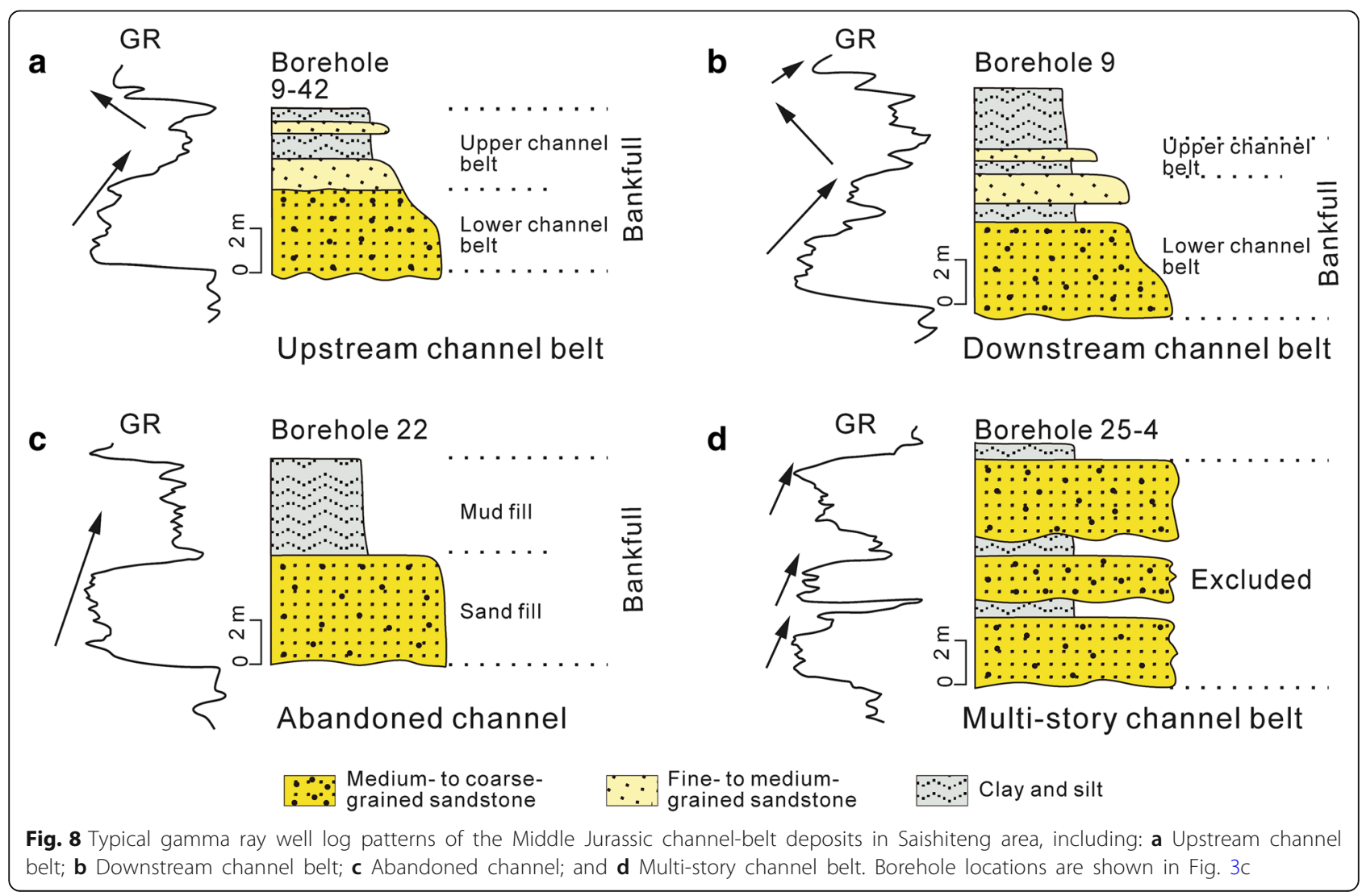


for the measurement of true thickness of single-story channel-belts (Li et al. 2016).

\subsection{Channel-belt thickness measurement}

Complete channel-belt deposits are formed during a bankfull stage and can be subdivided into the lower channel belt deposits and the upper channel belt deposits (Fig. 1b; Bridge and Tye 2000). The lower channel-belt deposits have relatively high sandy components which can be easily identified by well log curves, but it should be noted that the lower channel-belt only represents a portion of the channel-forming discharge (Bridge and Tye 2000). The top boundary of the upper muddy channel belt can be recognized by observing the maximum deflection to the shale baseline on well log curves (Fig. 8; Xu et al. 2017). There are several coal seams developed in the Middle Jurassic of Saishiteng area, which facilitate the identification of a complete preservation of channel-belt deposits (Fig. 4). The appearance of coal seams can also be used as a sign to identify the top of a channel belt. In this study, bankfull thickness (a complete succession of channel-belt thickness) was measured to estimate the palaeodrainage area and length by channel-belt scaling relationship.

\section{Results}

In this study, data from 332 bankfull thickness were measured in 81 GR well logs, which basically cover the major fluvial axes of Rivers A, B, and C. The channelbelt thickness distribution characteristics of each river in Dameigou and Shimengou Formations were analyzed, showing that the thicknesses generally range from $3.6 \mathrm{~m}$ to $13.2 \mathrm{~m}$ (Table 1; Figs. 9 and 10). In general, the thinnest $10 \%$ of channel-belt thickness data may represent distributary channels or tributaries near the major fluvial axes, while the thickest $10 \%$ may represent multi-story channel or valley-fill deposits (Xu et al. 2017). In order to exclude the interference of these outliers to the true channel-belt thickness of three major rivers, we only used the remaining $80 \%$ of the channel-belt thickness data to reconstruct the drainage area. The raw data and truncated data of Rivers A, B, and C in Dameigou and Shimengou Formations are presented in Figs. 9 and 10.

\subsection{Channel-belt thickness of Dameigou Formation}

The channel-belt thicknesses of Dameigou Formation in Saishiteng area range from $5 \mathrm{~m}$ to $13.2 \mathrm{~m}$. The thickness distribution characteristics of each river are distinct (Fig. 9; Table 1). The channel-belt thicknesses from raw data of River A in the northwest mainly concentrated at 9-12 m, accounting for $62 \%$ of the total data, followed by $25 \%$ of the data at $7-9 \mathrm{~m}$, and the proportions of data distributed at 6-7 $\mathrm{m}$ and $12-14 \mathrm{~m}$ are relatively low. The channel-belt thicknesses from raw data of River $\mathrm{B}$ range from $6 \mathrm{~m}$ to $13 \mathrm{~m}$, including a major peak at $8-10 \mathrm{~m}$. The thickness at 7-8 $\mathrm{m}$ can account for $18 \%$, and the proportion of remaining data is relatively low. River $C$ in the southeast shows a narrower range of channel-belt thicknesses, ranging from $5 \mathrm{~m}$ to $11 \mathrm{~m}$, with an obvious major peak at 7-8 $\mathrm{m}$ which account for $35 \%$ of the total data, and there are no channel-belts thicker than $11 \mathrm{~m}$.

After excluding $10 \%$ of the thickest and $10 \%$ of the thinnest outliers, truncated thickness data can better reflect the true channel-belt thickness. River $\mathrm{A}$ has the largest truncated thickness, ranging from $7 \mathrm{~m}$ to $12 \mathrm{~m}$, River B has moderate thickness data at 7-11 m, while the truncated thickness of River $\mathrm{C}$ is the thinnest, ranging from $6 \mathrm{~m}$ to $10 \mathrm{~m}$, and $88 \%$ data of River $\mathrm{C}$ are thinner than $9 \mathrm{~m}$. As a whole, the distribution range of truncated thickness data is more concentrated than the raw data, and the distribution trend is basically similar to those of the raw data (Fig. 9).

\subsection{Channel-belt thickness of Shimengou Formation}

The channel-belt thicknesses of Shimengou Formation in Saishiteng area range from $3.6 \mathrm{~m}$ to $10.3 \mathrm{~m}$, with a narrower range relative to that of Dameigou Formation (Fig. 10; Table 1). 80\% of channel-belt thicknesses from the raw data of River A concentrated at 6-9 m, with a right-skewed distribution pattern. The raw data distribution of River B shows a clear major peak at 5-6 m, accounting for $40 \%$ of the total data, which also displays a strong right-skewed pattern. The channel-belt thickness of River $C$ is clustered in thickness ranging from $3 \mathrm{~m}$ to $9 \mathrm{~m}$, with most data clustering at 4-6 $\mathrm{m}$ and a few data ranging from $3 \mathrm{~m}$ to $4 \mathrm{~m}$ and $6 \mathrm{~m}$ to $9 \mathrm{~m}$, respectively.

The truncated thickness of Shimengou Formation shows a narrower range, from $4.2 \mathrm{~m}$ to $9.4 \mathrm{~m}$. The truncated thickness of River A clustered at 6-10 m with the

Table 1 Channel-belt thickness of three major Middle Jurassic fluvial systems in Saishiteng area of the northern Qaidam Basin

\begin{tabular}{|c|c|c|c|c|c|c|}
\hline \multirow{3}{*}{$\begin{array}{l}\text { River } \\
\text { system }\end{array}$} & \multicolumn{3}{|c|}{ Dameigou Formation } & \multicolumn{3}{|c|}{ Shimengou Formation } \\
\hline & Raw thickness & Truncated thickness & Truncated thickness & Raw thickness & Truncated thickness & Truncated thickness \\
\hline & Range (m) & Range (m) & Mean (m) & Range (m) & Range (m) & Mean $(\mathrm{m})$ \\
\hline River A & $6.4-13.2$ & $7.4-11.8$ & 9.8 & $5.3-10.3$ & $6.4-9.4$ & 7.4 \\
\hline River B & $6.4-12.9$ & $7.3-10.6$ & 8.9 & $4.3-9.3$ & $5-8.4$ & 6.2 \\
\hline River C & $5-10.6$ & $6.2-9.6$ & 7.9 & $3.6-8.6$ & $4.2-6.9$ & 5.4 \\
\hline
\end{tabular}



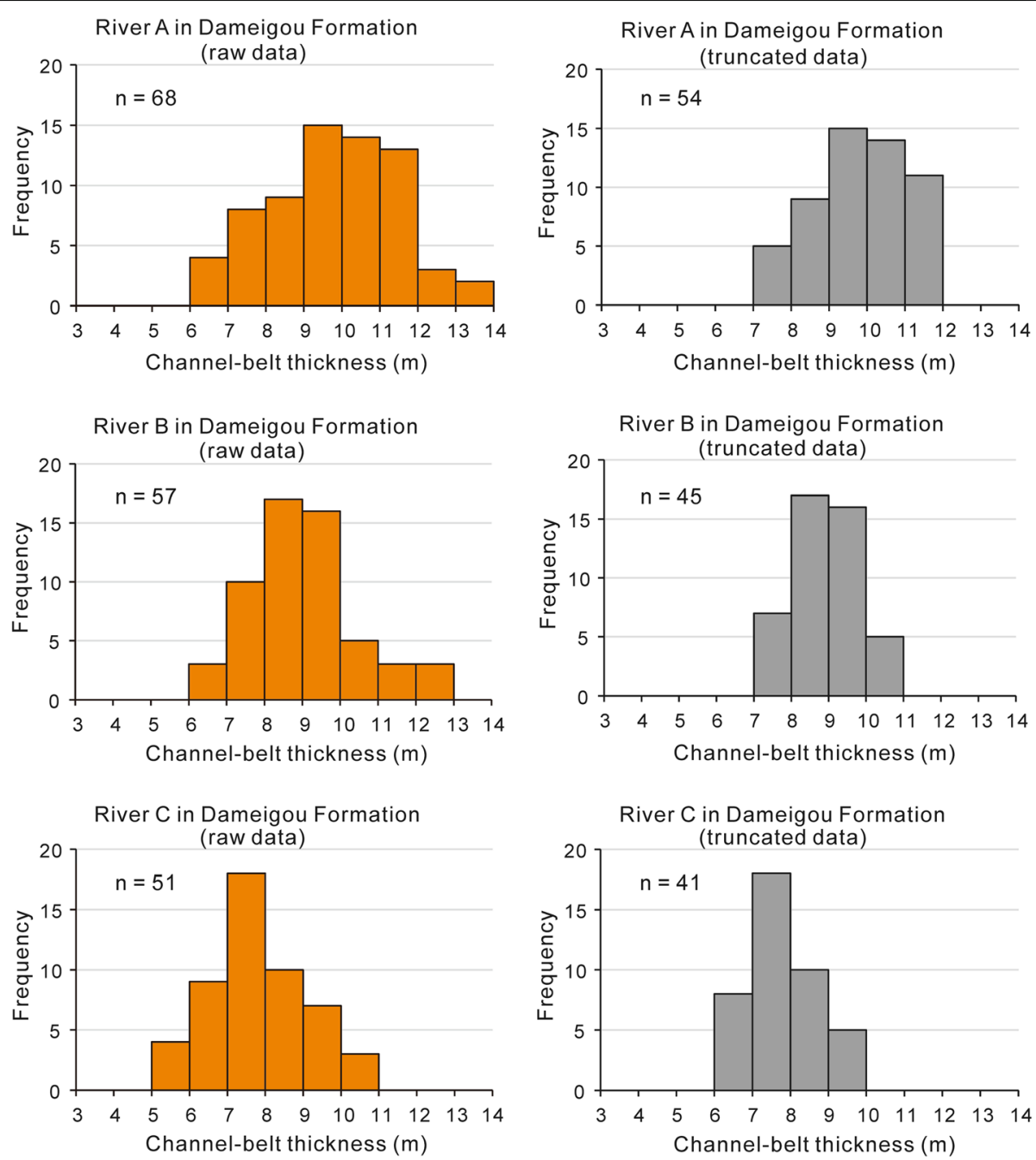

Fig. 9 Channel-belt thickness histograms of three major fluvial systems of Dameigou Formation, Saishiteng area

largest overall thickness in this period. River B has thickness data ranging from 5 to $9 \mathrm{~m}$, among which the 5-6 $\mathrm{m}$ data accounting for $49 \%$. The truncated thickness of River $\mathrm{C}$ has the narrowest range compared to Rivers A and B, which clustered at $4-7 \mathrm{~m}$, and $85 \%$ of the data are thinner than $6 \mathrm{~m}$. The overall thickness of the three major fluvial systems in Shimengou Formation decreased significantly compared with that in Dameigou Formation (Fig. 10).

\subsection{Comparison of channel-belt thickness patterns}

The cumulative frequency plot of truncated thickness shows the scale of river dimension during Dameigou and Shimengou Formations. The gentler the cumulative frequency slope, the larger the river scale (Fig. 11). The mean truncated thicknesses of River A in the northwest during Dameigou and Shimengou Formations were $9.8 \mathrm{~m}$ and $7.4 \mathrm{~m}$, respectively. The cumulative percentage curve of River A channel-belt thickness in Dameigou Formation was the gentlest, indicating that River A has the largest scale during this period, while the scale of River A in Shimengou Formation decreased. River B in the center has a mean channel-belt thickness of $8.9 \mathrm{~m}$ in Dameigou Formation, which was only thinner than that of River A during this period, and the mean channel-belt thickness of River B in Shimengou Formation reduced to $6.2 \mathrm{~m}$. The mean channel-belt thicknesses of River $C$ in the southeast during Dameigou and Shimengou Formations were $7.9 \mathrm{~m}$ and $5.4 \mathrm{~m}$, respectively. River $\mathrm{C}$ has the steepest cumulative percentage curve of channel-belt thickness in Shimengou Formation, indicating that the scale of River C was the smallest of the three major Middle Jurassic fluvial systems (Table 1; Fig. 11).

\section{Discussion}

Comprehensive studies have been conducted on the scaling relationship between channel-belt thickness (bankfull thickness) and drainage area (Blum et al. 2013; 

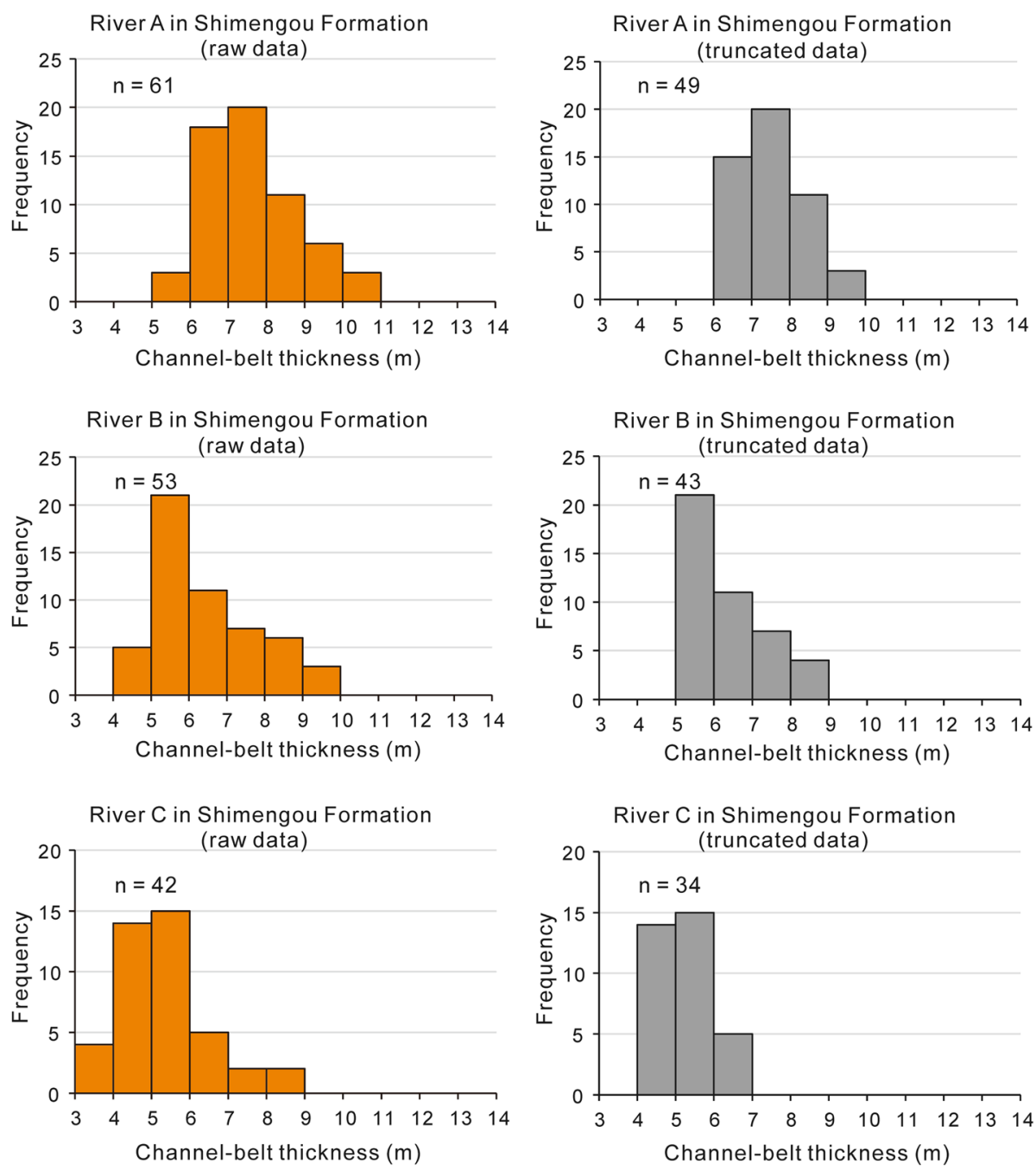

Fig. 10 Channel-belt thickness histograms of three major fluvial systems in Shimengou Formation, Saishiteng area

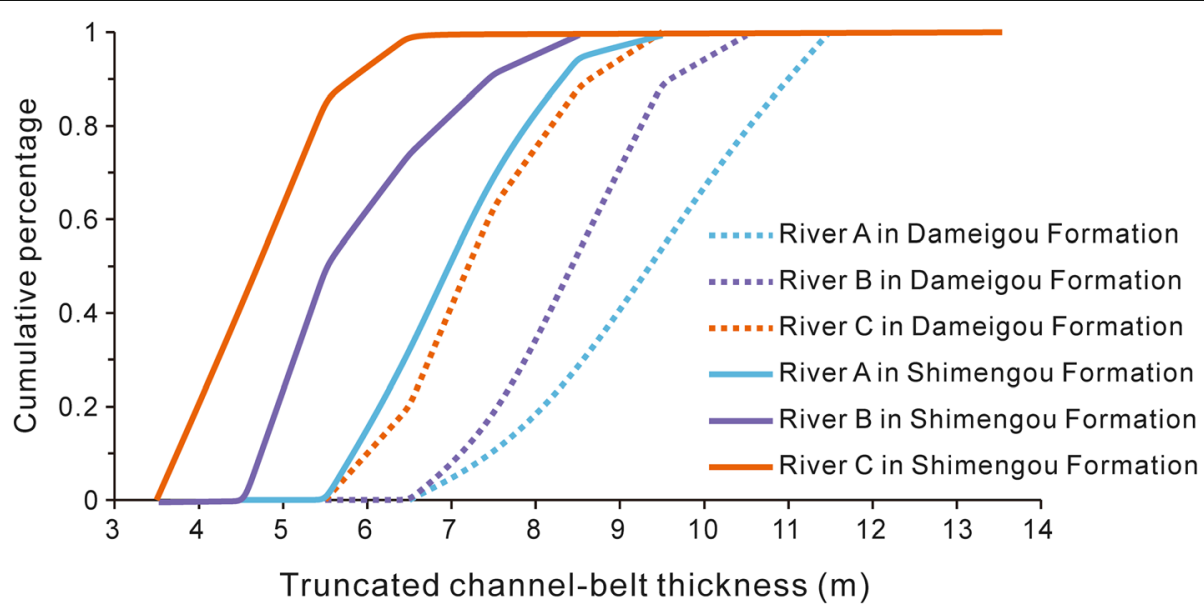

Fig. 11 Cumulative percentage plots of truncated thickness of the three major Middle Jurassic fluvial systems in Saishiteng area of the northern Qaidam Basin 
Davidson and Hartley 2014; Xu et al. 2017; Milliken et al. 2018) in Saishiteng area, northern Qaidam Basin. In this study, the channel-belt scaling relationship established by Blum et al. (2013) was used to estimate the drainage area of three major fluvial systems in Saishiteng area during the deposition of Dameigou and Shimengou Formations (Fig. 2). The coupling relationship between drainage changes and basin tectonic evolution will be discussed based on these estimations.

\subsection{Drainage area}

As one of the important sediment transport systems in Saishiteng area, River A continuously carried siliciclastic material from the southern Qilian Mountains to study area during the Middle Jurassic ( $\mathrm{Li}$ et al. 2016; Qian et al. 2018). The drainage area of River A in Dameigou Formation was $63.0 \times 10^{3} \mathrm{~km}^{2}$, and that of Shimengou Formation was $32.3 \times 10^{3} \mathrm{~km}^{2}$, which was about $50 \%$ of the former (Table 2). In general, when the source-to-sink system is in dynamic equilibrium, the dimension of linked components should have a corresponding proportional relationship (Romans and Graham 2013; Bhattacharya et al. 2016). The palaeogeographic map of Saishiteng area reconstructed by $\mathrm{Li}$ et al. (2016) shows that the flow direction of River A in the Shimengou Formation was skewed towards the west compared to that of Dameigou Formation. Correspondingly delta area decreased, indicating that the amount of sediment supplied by River A to the study area reduced, which corresponds to the conclusion that the drainage area decreased by channel-belt scaling relationship (Fig. 5; Table 2). Provenance analysis of detrital zircons shows that the sediments carried by River B in the study area are also from the southern Qilian Mountains (Qian et al. 2018). River B shows a drainage area of $50.1 \times 10^{3} \mathrm{~km}^{2}$ in the Dameigou Formation, and decreased to $21.2 \times 10^{3}$ $\mathrm{km}^{2}$ in the Shimengou Formation, which was about $42 \%$ of the former (Table 2). The reconstructed palaeogeographic map (Li et al. 2016; Fig. 5) indicates that the Middle Jurassic River B formed a relatively large delta in the central study area, and the channel position migrated northwards from the Dameigou Formation to the Shimengou Formation. River $\mathrm{C}$ was also mainly originated in the southern Qilian Mountains in the
Middle Jurassic, with its drainage area estimated to be $37.7 \times 10^{3} \mathrm{~km}^{2}$ for the Dameigou Formation, and $15.3 \times 10^{3} \mathrm{~km}^{2}$ for the Shimengou Formation, which reduced by about $41 \%$ compared to that of the former (Table 2), and the corresponding delta area in the palaeogeographic map also obviously reduced (Fig. 5). On the whole, for the three major rivers developed in the northwest to the southeast of the study area, River A showed the largest drainage area, followed by River $\mathrm{B}$ and River C, both in the Dameigou and Shimengou Formations. The drainage area of the same river decreased significantly from the Dameigou Formation to the Shimengou Formation, which can be mutually confirmed by the river scale in the palaeogeographic map (Fig. 5; Table 2).

\subsection{Drainage basin tectonic evolution}

Sømme et al. (2009) shows that the length of the longest river channel is positively correlated with drainage area. However, measurement of river length is very difficult for fluvial system in deep time. As a good proxy for length of the longest river channel, the drainage basin length can be estimated by channel-belt thickness (Fig. 1). Based on the study of Xu et al. (2017) for drainage basin length and channel-belt thickness, the relationship between drainage basin length (y) and channel-belt thickness (x) can be estimated as: $\mathrm{y}=1.2206 \times^{4.3297}\left(R^{2}=0.9748 ; R^{2}\right.$ is coefficient of determination). Using this equation, the drainage basin length of River A is estimated as $300.4 \mathrm{~km}$ in the Dameigou Formation and $154.3 \mathrm{~km}$ in the Shimengou Formation, demonstrating a shortening of $146.1 \mathrm{~km}$ during deposition of the latter. The drainage basin lengths of River B in Dameigou and Shimengou Formations are estimated as $239 \mathrm{~km}$ and $101.3 \mathrm{~km}$, respectively, reducing $137.7 \mathrm{~km}$ during deposition of the latter. The drainage basin length of river $C$ is estimated as $180.2 \mathrm{~km}$ in the Dameigou Formation, and $73.1 \mathrm{~km}$ in the Shimengou Formation, reducing $107.1 \mathrm{~km}$ during deposition of the latter. Generally, for the same river, the drainage basin length significantly reduced from the Dameigou Formation to the Shimengou Formation, and the shortened distances for each river are basically similar (Table 2). In addition, during the same period, drainage basin of River A showed

Table 2 Drainage area and drainage basin length of three major Middle Jurassic fluvial systems in Saishiteng area of the northern Qaidam Basin

\begin{tabular}{lllll}
\hline $\begin{array}{l}\text { River } \\
\text { system }\end{array}$ & \multicolumn{2}{l}{ Dameigou Formation } & & \multicolumn{2}{l}{ Shimengou Formation } \\
\cline { 2 - 5 } & $\begin{array}{l}\text { Drainage area } \\
\left(\times 10^{3} \mathrm{~km}^{2}\right)\end{array}$ & $\begin{array}{l}\text { Drainage basin length } \\
(\mathrm{km})\end{array}$ & $\begin{array}{l}\text { Drainage area } \\
\left(\times 10^{3} \mathrm{~km}^{2}\right)\end{array}$ & $\begin{array}{l}\text { Drainage basin length } \\
(\mathrm{km})\end{array}$ \\
\hline River A & 63.0 & 300.4 & 32.3 & 154.3 \\
River B & 50.1 & 239.0 & 21.2 & 101.3 \\
River C & 37.7 & 180.2 & 15.3 & 73.1 \\
\hline
\end{tabular}


the greatest length, followed by River B, and that of River $\mathrm{C}$ as the shortest (Table 2).

The Late Triassic tectonic movements resulted in the uplift of Qilian Mountains and the relative subsidence of Qaidam Block (Jin et al. 2004). The Qaidam Block ended the history of long-term uplift and erosion by the end of Late Triassic, and began to receive net deposition since Jurassic. The Saishiteng Mountain was not uplifted, while the Qilian Mountains were uplifted and had provided siliciclastic materials continuously during the Middle Jurassic (Liu et al. 2017b; Qian et al. 2018). Rivers A, B, and $\mathrm{C}$ are the major channels for transporting sediments into Saishiteng depression, forming a local small-scale source-to-sink system in Qaidam Basin. Since the stretch direction of the southern Qilian Mountains is NW-SE (Jin et al. 2004) and the palaeo-shoreline was roughly west-to-east trended, River A in the northwest flows into the lake through a longer distance, River B, located in the middle, had a shorter distance, while River $\mathrm{C}$, located at the southeast, had a shortest length (Fig. 12). The pattern of these rivers length distribution is in consistent with the result derived from drainage basin reconstruction.

The basin evolution of the northern Qaidam Basin during Jurassic has been extensively investigated by a number of researchers (Shao et al. 2014; Du et al. 2017; Yan 2017; Qian et al. 2018). Analyses of palaeomagnetism, palaeotectonic stress field, subsidence history, balanced cross section and apatite fission track records (Wang et al. 2006; Zhan et al. 2008; Ren et al. 2009; Zeng et al. 2009) indicate that an extensional tectonic setting existed between the North China Plate and the Qaidam Block during the Early - early Middle Jurassic, while a collisional orogeny occurred in the late Middle Jurassic. In the Early Jurassic, there were several small fault basins in the northern Qaidam Basin, and the depocenter of the Middle Jurassic basin migrated to the front of the southern Qilian Mountains. Seismic sections show that the Middle Jurassic sedimentary strata on the northern Qaidam Basin are not controlled by normal faults and have the typical sedimentary characteristics of the depression basins, but the changes in tectonic setting have caused the basin to gradually transform from extension depression to compression depression (Yan 2017; Zeng et al. 2017). In general, the tectonic evolution will have a certain depositional response in the components of the sourceto-sink system. In this study, compared to that in the Shimengou Formation, the three major rivers in the Dameigou Formation have larger drainage area and longer drainage length, which indicates that the prototype basin is larger in this period, and the "source" is more far away from the "sink", corresponding to the extension depression. The drainage area and drainage basin length in Shimengou Formation decreased, which correlates with the reversal of tectonic stress. The Qilian Mountains were pushed southwards by the compression of the North China Plate, forming the area-reduced compression depression (Fig. 13). The variations of channelbelt thickness, drainage area and drainage basin length of the source-to-sink system during the Middle Jurassic Dameigou Formation to Shimengou Formation are likely to be the performance of the Yanshan movement in the northern Qaidam Basin.



Fig. 12 Schematic diagram of the Middle Jurassic source-to-sink system in Saishiteng area of the northern Qaidam Basin 




Compared with the source-to-sink system of passive continental margin basin, the scale of source-to-sink system of continental basin in Saishiteng area is relatively small, and the relationship among source-to-sink system components is often more sensitive. In the Middle Jurassic, Saishiteng area belongs to a depression basin with a relatively gentle slope. The stable meandering river depositional system is mainly developed in the drainage area, while the sedimentary area mainly consists of delta depositional system. The study shows that the larger drainage area is consistent with a longer transport path, and the river with a larger bankfull thickness carries more sediments and forms a channel-belt with a larger thickness, which corresponds to larger delta deposits in the sedimentary area. This scaling relationship indicates that the source-to-sink system is in mass-balance with no obvious intermediate storage or loss of sediment, but the accurate quantitative relationship among the components of source-to-sink system in Saishiteng area needs to be established and verified by measuring more data in subsequent work. In addition, the estimated drainage basin length reveals the distance between Qilian Mountains and Saishiteng area in the Middle Jurassic, which is conducive to provenance analysis. In the case that most strata of the northern part were eroded in the study area, the corresponding drainage area is of great significance for the reconstruction of palaeogeography.

\subsection{Uncertainties and limitations}

According to Charles Lyell's concept that "the present is the key to the past" in Earth science (Romano 2015), it can be assumed that the scaling relationships among components in the source-to-sink system have universal applicability at different space-time scales, which enables us to reconstruct the deep-time drainage landscape based on the preserved stratigraphic records. Research cases have demonstrated the reliability of this approach in deep-time studies (Sømme et al. 2013). However, this method must be applied cautiously in deep-time studies, and the impact of various error factors should be taken into account.

In different climatic regions, rivers with similar drainage areas often have different channel-belt thicknesses, so it is necessary to pay attention to the influence of climate on the channel-belt thickness. The Saishiteng area belongs to a small continental basin source-to-sink system, palaeomagnetic data indicate that the Middle Jurassic study area is at 8.5 degrees north latitude, and the chemical weathering degree of sediments and sporopollen assemblages indicate a continuous warm and humid 
palaeoclimate (Yang et al. 2006; Shao et al. 2014; Du et al. 2017). The tectonic stress of the Middle Jurassic northern Qaidam Basin changed, but it is still a depression basin as a whole, and the climate and tectonic setting were all included in the database of scaling relationships in the source-to-sink system established by Blum et al. (2013).

It is inevitable that there will be certain errors in measuring channel-belt thickness by well logs. Bankfull thickness may be underestimated when the upper channel deposit was eroded by an overlying channel, or overestimated when the upper channel deposit was mixed with overbank deposits (Lorenz et al. 1985). Distributary channels, tributaries near the major channel, multi-story channel deposits and valley-fill deposits will all interfere with the measurement results, although truncated thickness was used to minimize the impact of these factors. There are few exposed Jurassic outcrops in the study area, but measurements should be made in conjunction with field outcrops as much as possible and verified with the well logs data in further work.

The Middle Jurassic was only preserved in the southern parts of the study area, while the strata of the northern part were eroded due to late tectonic uplift in late periods. Therefore, accurate palaeogeographic reconstruction of the whole area is very difficult using traditional methods. Drainage areas of the three major rivers were restored quantitatively by channel-belt scaling relationship, but the boundaries among drainage basins of these rivers are still not precisely defined. A single method is often unable to fully reconstruct the complex geomorphic units of a source-to-sink system, which requires further understanding of the source-to-sink system in the northern Qaidam Basin by means including sedimentary volume backfilling, and thermal chronology of clastic minerals.

\section{Conclusions}

1) Based on a database of 81 well logs, Middle Jurassic single-story channel-belts were identified in the Saishiteng area, northern Qaidam Basin, and channelbelt thickness of three major rivers developed in the study area were measured. The mean channel-belt thicknesses of River A, River B and River C in Dameigou Formation were $9.8 \mathrm{~m}, 8.9 \mathrm{~m}$ and $7.9 \mathrm{~m}$; and those in Shimengou Formation were $7.4 \mathrm{~m}$, $6.2 \mathrm{~m}$ and $5.4 \mathrm{~m}$, respectively.

2) Channel-belt scaling relationship was applied to source-to-sink system analysis, and drainage area and drainage basin length of the three major rivers in the Middle Jurassic were reconstructed. The drainage areas of River A, River B and River C in the Dameigou Formation were $63.0 \times 10^{3} \mathrm{~km}^{2}, \quad 50.1 \times 10^{3} \mathrm{~km}^{2}$ and $37.7 \times 10^{3} \mathrm{~km}^{2}$; and those in the Shimengou Formation were $32.3 \times 10^{3} \mathrm{~km}^{2}, \quad 21.2 \times 10^{3} \mathrm{~km}^{2}$ and $15.3 \times 10^{3} \mathrm{~km}^{2}$, respectively. The drainage basin lengths of River A, River B and River C in the Dameigou Formation were $300.4 \mathrm{~km}, 239 \mathrm{~km}$ and $180.2 \mathrm{~km}$, and those in the Shimengou Formation were $154.3 \mathrm{~km}, 101.3 \mathrm{~km}$ and $73.1 \mathrm{~km}$, respectively.

3) For the small-scale source-to-sink system of continental basin in the study area, River A showed the greatest scale, followed by River B and River C both in Dameigou and Shimengou Formations, which was mainly determined by the stretch direction of provenance in the southern Qilian Mountains. Channel-belt thickness, drainage area and drainage basin length showed a decreasing trend from the Dameigou Formation to the Shimengou Formation for the same rivers, which is the response of the source-to-sink system to the tectonic transformation of extension to compression depression in the Middle Jurassic of the northern Qaidam Basin.

\section{Abbreviations}

GR: Gamma ray; SP: Spontaneous potential

\section{Acknowledgements}

We would like to thank Xiao-Min Zhu for constructive suggestion for the work. We also thank Jason Hilton for his constructive comments to improve the manuscript.

\section{Funding}

This research was supported by the National Natural Science Foundation of China (No. 41572090) and National Science and Technology Major Project (No. 2016ZX05041004-003).

\section{Availability of data and materials}

The datasets analyzed in the current study are not publicly available due to the confidentiality policy of production department but are available from the corresponding author on reasonable request.

\section{Authors' contributions}

$\mathrm{BQL}$ estimated drainage area of the three major rivers by using scaling relationships between drainage area and channel-belt thickness, and was a major contributor in writing the manuscript. LYS made a thorough revision to the manuscript. All authors read and approved the final manuscript.

Competing interests

The authors declare that they have no competing interests.

\section{Publisher's Note}

Springer Nature remains neutral with regard to jurisdictional claims in published maps and institutional affiliations.

\section{Author details}

${ }^{1}$ College of Geoscience and Surveying Engineering, China University of Mining and Technology (Beijing), Beijing 100083, China. ${ }^{2}$ School of Ocean Sciences, China University of Geosciences (Beijing), Beijing 100083, China.

Received: 20 November 2018 Accepted: 25 March 2019

Published online: 11 April 2019

\section{References}

Alexander, C.R., J.P. Walsh, and A.R. Orpin. 2010. Modern sediment dispersal and accumulation on the outer poverty continental margin. Marine Geology 270: 213-226.

Allen, P.A. 2005. Striking a chord. Nature 434: 961.

Allen, P.A. 2008. From landscapes into geological history. Nature 451 (7176): 274-276. 
Amorosi, A., V. Maselli, and F. Trincardi. 2016. Onshore to offshore anatomy of a Late Quaternary source-to-sink system (Po plain-Adriatic Sea, Italy). EarthScience Reviews 153: 212-237.

Anderson, J.B., D.J. Wallace, A.R. Simms, A.B. Rodriguez, R.W.R. Weight, and Z.P. Taha. 2016. Recycling sediments between source and sink during a eustatic cycle: Systems of Late Quaternary northwestern Gulf of Mexico Basin. EarthScience Reviews 153: 111-138.

Berryman, K., M. Marden, A. Palmer, K. Wilson, C. Mazengarb, and N. Litchfield. 2010. The post-glacial downcutting history in the Waihuka tributary of Waipaoa River, Gisborne district: Implications for tectonics and landscape evolution in the Hikurangi subduction margin, New Zealand. Marine Geology 270: $55-71$

Bhattacharya, J.P., P. Copeland, T.F. Lawton, and J. Holbrook. 2016. Estimation of source area, river paleo-discharge, paleoslope, and sediment budgets of linked deep-time depositional systems and implications for hydrocarbon potential. Earth-Science Reviews 153: 77-110.

Blum, M., J. Martin, K. Milliken, and M. Garvin. 2013. Paleovalley systems: Insights from quaternary analogs and experiments. Earth-Science Reviews 116: 128-169.

Blum, M.D., and J.H. Womack. 2009. Climate change, sea-level change, and fluvial sediment supply to Deepwater systems. In External controls on deep water depositional systems: Climate, sea-level, and sediment flux. SEPM Special Publication, ed. B. Kneller, O.J. Martinsen, and B. McCaffrey, vol. 92, 15-39.

Bridge, J.S., and R.S. Tye. 2000. Interpreting the dimensions of ancient fluvial channel bars, channels, and channel belts from wireline-logs and cores. AAPG Bulletin 84 (8): 1205-1228.

Carter, L., A.R. Orpin, and S.A. Kuehl. 2010. From mountain source to ocean sink - The passage of sediment across an active margin, Waipaoa sedimentary system, New Zealand. Marine Geology 270: 1-10.

Dai, J.S., X.S. Ye, L.J. Tang, Z.J. Jin, W.B. Shao, Y. Hu, and B.S. Zhang. 2003. Tectonic units and oil-gas potential of the Qaidam Basin. Chinese Journal of Geology 38 (3): 291-296 (in Chinese with English abstract).

Dang, Y.Q., Y. Hu, H.L. Yu, Y. Song, and F.Z. Yang. 2003. Petroleum geology of the northern Qaidam Basin, NW China. Beijing: Geological Publishing House (in Chinese).

Davidson, S.K., and A.J. Hartley. 2014. A quantitative approach to linking drainage area and distributive-fluvial-system area in modern and ancient endorheic basins. Journal of Sedimentary Research 84 (11): 1005-1020.

Davidson, S.K., and C.P. North. 2009. Geomorphological regional curves for prediction of drainage area and screening modern analogues for rivers in the rock record. Journal of Sedimentary Research 79 (10): 773-792.

Deng, S.H., Y.Z. Lu, Y. Zhao, R. Fan, Y.D. Wang, X.J. Yang, X. Li, and B.N. Sun. 2017. The Jurassic palaeoclimate regionalization and evolution of China. Earth Science Frontiers 24 (1): 106-142 (in Chinese with English abstract).

Du, J.J., S.A. Zhang, W.F. Xiao, and W. Jiang. 2017. Geochemistry characteristics of middle-lower Jurassic clastic rocks in the northern margin of Qaidam Basin and their geological significance. Journal of Earth Sciences and Environment 39 (6): 721-734 (in Chinese with English abstract).

Durkin, P.R., S.M. Hubbard, R.L. Boyd, and D.A. Leckie. 2015. Stratigraphic expression of intra-point-bar erosion and rotation. Journal of Sedimentary Research 85 (10): 1238-1257.

Feng, Z.Z. 2004. Single factor analysis and multifactor comprehensive mapping method - Reconstruction of quantitative lithofacies palaeogeography. Journal of Palaeogeography (Chinese Edition) 6 (1): 3-19 (in Chinese with English abstract).

Fuller, I.C., and M. Marden. 2010. Rapid channel response to variability in sediment supply: Cutting and filling of the Tarndale Fan, Waipaoa catchment, New Zealand. Marine Geology 270: 45-54.

Galloway, W.E. 1981. Depositional architecture of Cenozoic gulf coastal plain fluvial systems. In Recent and ancient nonmarine depositional environments: Models for exploration. SEPM Special Publication, ed. F.G. Etheridge, and R.M. Flores, vol. 31, 127-155.

Gibling, M.R. 2006. Width and thickness of fluvial channel bodies and valley fills in the geological record: A literature compilation and classification. Journal of Sedimentary Research 76 (5): 731-770.

Helland-Hansen, W., T.O. Sømme, O.J. Martinsen, I. Lunt, and J. Thurmond. 2016. Deciphering Earth's natural hourglasses: Perspectives on source-to-sink analysis. Journal of Sedimentary Research 86 (9): 1008-1033.

Holbrook, J., and H. Wanas. 2014. A fulcrum approach to assessing source-to-sink mass balance using channel paleohydrologic parameters derivable from common fluvial data sets with an example from the cretaceous of Egypt. Journal of Sedimentary Research 84 (5): 349-372.
Hovius, N. 1998. Controls on sediment supply by large rivers. In Relative role of Eustasy, climate, and tectonism in continental rocks. SEPM Special Publication, ed. K.W. Shanley, and P.J. McCabe, vol. 59, 2-16.

Hubbard, S.M., D.G. Smith, H. Nielsen, D.A. Leckie, M. Fustic, R.J. Spencer, and L. Bloom. 2011. Seismic geomorphology and sedimentology of a tidally influenced river deposit, lower cretaceous Athabasca oil sands, Alberta, Canada. AAPG Bulletin 95 (7): 1123-1145.

Jin, Z.J., M.L. Zhang, L.J. Tang, and J.C. Li. 2004. Evolution of Meso-Cenozoic Qaidam Basin and its control on oil and gas. Oil and Gas Geology 25 (6): 603608 (in Chinese with English abstract).

Li, M., L.Y. Shao, L. Liu, J. Lu, B. Spiro, H.J. Wen, and Y.H. Li. 2016. Lacustrine basin evolution and coal accumulation of the middle Jurassic in the Saishiteng coalfield, northern Qaidam Basin, China. Journal of Palaeogeography 5 (3): $205-220$.

Li, M., L.Y. Shao, J. Lu, B. Spiro, H.J. Wen, and Y.H. Li. 2014. Sequence stratigraphy and paleogeography of the middle Jurassic coal measures in the Yuqia coalfield, northern Qaidam Basin, northwestern China. AAPG Bulletin 98 (12): 2531-2550.

Li, Z.X., D.D. Wang, D.W. LV, Y. Li, H.Y. Liu, P.L. Wang, Y. Liu, J.Q. Liu, and D.D. Li. 2017. The geologic settings of Chinese coal deposits. International Geology Review 60 (5-6): 548-578.

Liu, Q.H., X.M. Zhu, S.L. Li, C.G. Xu, X.F. Du, H.Y. Li, and W.L. Shi. 2017a. Source-tosink system of the steep slope fault in the western Shaleitian uplift. Earth Science 42 (11): 1883-1896 (in Chinese with English abstract).

Liu, T.J., L.Y. Shao, D.Y. Cao, Q. Ju, J.N. Guo, and J. Lu. 2013. Forming conditions and resource assessment of Jurassic coal in northern Qaidam Basin. Beijing: Geological Publishing House (in Chinese).

Liu, X., S.F. Zhu, J.J. Du, C.L. Liu, Y. Qin, and J.T. Zhang. 2017b. Sedimentary characteristics of the Jurassic in western north margin of Qaidam Basin Journal of Palaeogeography (Chinese Edition) 19 (4): 595-608 (in Chinese with English abstract).

Lorenz, J.C., D.M. Heinze, J.A. Clark, and C.A. Searls. 1985. Determination of widths of meander-belt sandstone reservoirs from vertical downhole data, Mesaverde group, Piceance Creek basin, Colorado. AAPG Bulletin 69 (5): 710-721.

Lu, J., L.Y. Shao, Q. Ju, T.J. Liu, H.J. Wen, Y.H. Li, F.D. Zhang, and D. Gao. 2009. Coal petrography variation in the sequence stratigraphic frame of the Jurassic coal measures of Dameigou mine area in northern Qaidam Basin. Coal Geology and Exploration 37 (4): 9-14 (in Chinese with English abstract).

Miall, A.D. 2006. How do we identify big rivers? And how big is big? Sedimentary Geology 186 (1-2): 39-50.

Milliken, K.T., M.D. Blum, J.W. Snedden, and W.E. Galloway. 2018. Application of fluvial scaling relationships to reconstruct drainage-basin evolution and sediment routing for the cretaceous and Paleocene of the Gulf of Mexico. Geosphere 14 (2): 749-767.

Qian, T., Z.X. Wang, Y.Q. Liu, S.F. Liu, W.L. Gao, W.P. Li, J.J. Hu, and L.L. Li. 2018 Provenance analysis of the Jurassic in the northern Qaidam Basin: Stratigraphic sequence and LA-ICP-MS geochronology. Scientia Sinica Terrae 48 (2): 224-242 (in Chinese)

Ren, S.M., X.H. Ge, Y.J. Liu, D.W. Qiao, C.M. Yin, F. Neubauer, and J. Genser. The stress field of late Mesozoic-Cenozoic tectonics in the northern Qaidam basin, Northwest China: Evidences from the analysis of joints data. Geological Bulletin of China 2009;28(7):877-87 (in Chinese with English abstract).

Romano, M. 2015. Reviewing the term uniformitarianism in modern earth sciences. Earth-Science Reviews 148: 65-76.

Romans, B.W., and S.A. Graham. 2013. A deep-time perspective of land-ocean linkages in the sedimentary record. Annual Review of Marine Science 5 (1): 69-94.

Saucier, R.T. 1994. Geomorphology and Quaternary Geologic History of the Lower Mississippi Valley, vol. 1. Vicksburg: U. S. Army Engineer Waterways Experiment Station.

Shao, L.Y., M. Li, Y.H. Li, Y.P. Zhang, J. Lu, W.L. Zhang, Z. Tian, and H.J. Wen. 2014 Geological characteristics and controlling factors of shale gas in the Jurassic of the northern Qaidam Basin. Earth Science Frontiers 21 (4): 311-322 (in Chinese with English abstract).

Sømme, T.O., W. Helland-Hansen, O.J. Martinsen, and J.B. Thurmond. 2009 Relationships between morphological and sedimentological parameters in source-to-sink systems: A basis for predicting semi-quantitative characteristics in subsurface systems. Basin Research 21 (4): 361-387.

Sømme, T.O., C.A. Jackson, and M. Vaksdal. 2013. Source-to-sink analysis of ancient sedimentary systems using a subsurface case study from the MøreTrøndelag area of southern Norway: Part 1 - Depositional setting and fan evolution. Basin Research 25 (5): 489-511. 
Syvitski, J.P.M., and J.D. Milliman. 2007. Geology, geography, and humans battle for dominance over the delivery of fluvial sediment to the coastal ocean. The Journal of Geology 115 (1): 1-19.

Walsh, J.P., P.L. Wiberg, R. Aalto, C.A. Nittrouer, and S.A. Kuehl. 2016. Source-tosink research: Economy of the Earth's surface and its strata. Earth-Science Reviews 153: 1-6.

Wang, X.G., D.Y. Cao, W.F. Zhan, and T.J. Liu. 2006. The Meso-Cenozoic basin type and tectonic evolution in the northern margin region of the Qaidam Basin. Geoscience 20 (4): 592-596 (in Chinese with English abstract).

Willis, B.J. 1989. Palaeochannel reconstructions from point bar deposits: A threedimensional perspective. Sedimentology 36 (5): 757-766.

Wu, Y.Y., Y. Song, C.Z. Jia, B.C. Guo, Q.Q. Zhang, H.C. Ji, J. Li, and J.P. Zhang. 2005. Sedimentary features in a sequence stratigraphic framework in the north area of Qaidam Basin. Earth Science Frontiers 12 (3): 195-203 (in Chinese with English abstract).

Xu, J., J.W. Snedden, W.E. Galloway, K.T. Milliken, and M.D. Blum. 2017. Channelbelt scaling relationship and application to Early Miocene source-to-sink systems in the Gulf of Mexico basin. Geosphere 13 (1): 1-22.

Yan, Z.D. 2017. Study on the Jurassic Prototype Basin in the Western part of the Northern Qaidam Basin (Master's thesis). Xi'an: Northwest University (in (hinese).

Yang, P., Z.K. Xie, X.J. Yuan, S.J. Zhu, and D.B. Yi. 2006. Palaeoecological characteristics and its palaeogeographic significance of the Jurassic in northern margin of Qaidam Basin. Journal of Palaeogeography (Chinese Edition) 8 (2): 165-173 (in Chinese with English abstract).

Yang, Y.T., B.M. Zhang, W. Li, and H. Qu. 2000. Study of Jurassic stratigraphic sequence and sedimentary facies in north of Qaidam Basin. Earth Science Frontiers 7 (3): 145-151 (in Chinese with English abstract).

Zeng, C.L., B. Jiang, M. Zhang, C.M. Yin, and C.Y. Wang. 2009. Tectonic activities and apatite fission-track records in the northern margin of Qaidam Basin. Journal of Oil and Gas Technology 31 (2): 20-24 (in Chinese with English abstract).

Zeng, X., J.X. Tian, G.R. Yang, B. Wang, Z.Q. Guo, W. Wang, and H.L. Zhang. 2017. Structure characteristics and petroleum geological significance of Jurassic sags at the northern margin of Qaidam Basin. China Petroleum Exploration 22 (5): 54-63 (in Chinese with English abstract).

Zhan, W.F. L. Lin, H.B. Sun, and J.F. Sun. 2008. Tectonic evolution and structural control of coal in northern margin of Qaidam Basin coal-bearing zone. Coal Geology of China 20 (10): 25-27, 33 (in Chinese with English abstract).

Zhang, H. 1998. Jurassic coal-bearing strata and coal accumulation pattern in northwestern China. Beijing: Geological Publishing House (in Chinese).

Zhang, J.L., S.S. Liu, J.Z. Li, L.L. Liu, H.M. Liu, and Z.Q. Sun. 2017. Identification of sedimentary facies with well logs: An indirect approach with multinomial logistic regression and artificial neural network. Arabian Journal of Geosciences 10 (11): 247

Zhang, P.F. 1990. Sedimentary petrology. Beijing: China Coal Industry Publishing House (in Chinese).

Zhao, W.Z., J.Q. Jin, L.Q. Xue, Q.R. Meng, and C.Y. Zhao. 2000. Formation and evolution of Jurassic Prototype Basin in Northwest China. Beijing: Geological Publishing House (in Chinese).

\section{Submit your manuscript to a SpringerOpen ${ }^{\circ}$ journal and benefit from:}

- Convenient online submission

- Rigorous peer review

- Open access: articles freely available online

- High visibility within the field

- Retaining the copyright to your article

Submit your next manuscript at $\boldsymbol{\nabla}$ springeropen.com 